Cornell Law Library

Scholarship@Cornell Law: A Digital Repository

Cornell Law Faculty Publications

Faculty Scholarship

Fall 1980

\title{
Client Perjury: The Kutak Commission and the Association of Trial Lawyers on Lawyers, Lying Clients, and the Adversary System
}

Charles W. Wolfram

Cornell Law School, charlesw.wolfram@yahoo.com

Follow this and additional works at: http://scholarship.law.cornell.edu/facpub

Part of the Ethics and Professional Responsibility Commons, and the Legal Profession Commons

\section{Recommended Citation}

Wolfram, Charles W., "Client Perjury: The Kutak Commission and the Association of Trial Lawyers on Lawyers, Lying Clients, and the Adversary System" (1980). Cornell Law Faculty Publications. Paper 1271.

http://scholarship.law.cornell.edu/facpub/1271

This Article is brought to you for free and open access by the Faculty Scholarship at Scholarship@Cornell Law: A Digital Repository. It has been accepted for inclusion in Cornell Law Faculty Publications by an authorized administrator of Scholarship@Cornell Law: A Digital Repository. For more information, please contact jmp8@cornell.edu. 


\title{
Client Perjury: The Kutak Commission and the Association of Trial Lawyers on Lawyers, Lying Clients, and the Adversary System
}

\author{
Charles W. Wolfram
}

Attorney involvement in client perjury is a restive issue that does not admit of easy resolution. Many other issues are addressed by the Kutak Commission ${ }^{1}$ in its proposed revision of the American Bar Association's recommended rules of attorney conduct. ${ }^{2}$ But few have raised such a spirited professional ${ }^{3}$ and public ${ }^{4}$ debate as the Commission's broad proposal for required disclosure of client dishonesty. Whistle blowing by counsel is mandated in some instances, ${ }^{5}$ permitted in the attorney's discretion in others. ${ }^{6}$ Counsel for parties in negotiation are

Charles W. Wolfram is Professor of Law, University of Minnesota; Affiliated Scholar, American Bar Foundation Class Action Project; Reporter, Minnesota State Bar Association (MSBA) Committee to Study the Kutak Commission Report. A.B., 1959, Notre Dame; LL.B., 1962, University of Texas.

The views expressed herein are solely those of the author.

1. For a discussion of the Kutak Commission Report, see Report of the MSBA Committee to Study the Kutak Commission Report, George C. King,.Chairman, 37 Bench \& Bar of Minn. 63-89 (July/Aug. 1980).

2. American Bar Association, Commission on Evaluation of Professional Standards, Model Rules of Professional Conduct (Discussion Draft, Chicago: American Bar Association, Jan. 30, 1980) [hereinafter cited as the Kutak-ABA proposal]. The Commission is chaired by Robert J. Kutak of Omaha, Nebraska, by whose name the Commission is often popularly referred to. The Commission has held hearings around the country and has widely solicited commentary. The announced program of the Commission is to redraft its proposal for release to the public in May 1981. See also James S. Granelli, Bar Parley: Hot Issues Put on Ice, Nat'l L.J., Aug. 18, 1980, at 6, col. 1.

3. See, e.g., Association of Trial Lawyers of America Annual Convention, 49 U.S.L.W. 2075 (July 29, 1980) (report of endorsement by ATLA Board of Governors of opposition to Kutak Commission proposal because of its decreased protection of client confidentiality); Richard E. Gerstein \& Marcia Christensen, Criminal Justice: New Criminal Code and Jury Reform Backed, Nat'l L.J., Aug. 4, 1980, at 28, col. 3, col. 4 (opposition to Kutak Commission's criminal defense client perjury rules on part of ABA Criminal Justice Section); Leonard H. Gilbert, General Practice: Challenges to Define Role of the Lawyer, Nat'l L.J., Aug. 4, 1980, at 41, col. 1 (opposition of ABA Section of General Practice to substantial portions of Kutak Commission proposal).

4. See, e.g., Philip M. Stern, Lawyers and Ethics, N.Y. Times, Aug. 4, 1980, at A21, col. 2; 48 U.S.L.W. 2805 (June 10, 1980) (United States Attorney General communication to Kutak Commission urging strengthening of rule [1.7(c)(2)] on discretionary reporting of "deliberately wrongful act" by client to require attorney withdrawal if discretionary disclosure is not made).

5. Kutak-ABA proposal, Rule 1.7(b) (lawyer must disclose information appearing necessary "to prevent the client from committing an act that would result in death or serious bodily harm to another person" and to the extent otherwise required by law or other rules); id., Rule 4.2(b) (disclosures mandated in course of serving as negotiator for client).

6. Id., Rule 1.7(c) (disclosure permitted "to the extent it appears necessary to prevent or rectify the consequences of a deliberately wrongful act by the client" unless attorney has been employed after the act occurs to represent the client concerning it); id., Rule 1.13(c) (attorney for entity such as a corporation or a union may make public disclosure of client confidences in order to remedy action or inaction of highest authority of organization that is clearly a violation of law). 
carefully circumscribed in presenting misleading information to others. ${ }^{7}$ And the lawyer whose client commits known perjury on the witness stand is under an explicit obligation to correct the perjury. ${ }^{8}$ All of these rules are part of the Commission's thematic development of a broad social dimension to the lawyer's work-a dimension that, in the Commission's view, requires more explicit recognition of the lawyer's obligations to third parties and to social institutions such as the courts to assist them in their work. The range of issues presented is very extensive, and the present review will deal only with the client perjury problem.

A self-described counterproposal ${ }^{9}$ to the Kutak-ABA discussion draft has been offered by Professor Monroe Freedman's draft rules for the Association of Trial Lawyers of America. ${ }^{10}$ Expanding very significantly a criminal defense position that Freedman has championed for 15 years, ${ }^{11}$ the Freedman-ATLA proposal for the first time in American jurisprudence ${ }^{12}$ would require the lawyer-in both civil and criminal cases, unless representing a governmental body-to assist the client in presenting perjured testimony. ${ }^{13}$ Expressly rejecting the Kutak Commission's delineation of a public dimension to the responsibilities of a lawyer, the Freedman-ATLA draft proceeds on the quite different belief that the primary value is that of assuring the most effective protection of the attorney-client relationship between private client and his or her lawyer. ${ }^{14}$ Truth is to that extent subordinated to far-reaching protection of the relationship. The contrast between the Freedman-ATLA proposal and the Kutak Commission draft thus presents in sharp relief the basic policy issues involved in the client perjury debate.

\section{The Varieties of Client Perjury}

Client perjury may be presented to a lawyer in many forms. It may arise on either side in a criminal or civil case. The client's intention to commit perjury may be revealed long before any suit is filed, making withdrawal by the lawyer a simple matter that would not compromise any secret of the client. Or it may be revealed much later when withdrawal without disclosure would be difficult or when a judge whose permission is required for withdrawal would not permit withdrawal for any reason. Or the lawyer may not learn of the client's intent to commit perjury until it surprisingly occurs. Indeed, the lawyer may not realize

7. Id., Rule 4.2(b).

8. Id., Rule 3.1(b).

9. See Theodore I. Koskoff, Introduction, in Commission on Professional Responsibility, Roscoe Pound-American Trial Lawyers Foundation, The American Lawyer's Code of Conduct ii (Public Discussion Draft, Washington, D.C.: Roscoe Pound-American Trial Lawyers Foundation, June 1980).

10. See American Lawyer's Code of Conduct, supra note 9. The June 1980 draft was authored by Monroe H. Freedman and is said to reflect extensive comments by the members of the ATLA Commission on Professional Responsibility, but has not been finally approved by it thereinafter cited as the Freedman-ATLA proposal]. Id. at copyright page; Irwin Birnbaum, Preface, in id. at 1.

11. See, e.g., Monroe H. Freedman, Professional Responsibility of the Criminal Defense Lawyer: The Three Hardest Questions, 64 Mich. L. Rev. 1469 (1966); Id., Lawyers' Ethics in an Adversary System (Indianapolis: Bobbs-Merrill Co., 1975).

12. No extant American authority has been discovered that purports to require attorney participation in the undisclosed presentation of client perjury in a civil case. See text at note 77 infra.

13. See Freedman-ATLA proposal, Rule 1.2; id., Illustrative Cases 1(b), 1(i), 6(a).

14. See id., Comment, at 104-7. 
that testimony already given by the client was false until this is revealed or learned later.

\section{The Kutak Commission Draft}

The proposal of the Kutak Commission would have the lawyer confront these problems in the following ways. The lawyer may not present evidence that the lawyer "is convinced beyond a reasonable doubt is false." 1 If the lawyer later discovers the falsity of the testimony "the lawyer shall disclose that fact and take suitable measures to rectify the consequences, even if doing so requires disclosure of a confidence of the client or disclosure that the client is implicated in the falsification." ${ }^{16}$ If the lawyer has reason to believe that the client does not understand these limitations on the lawyer's assistance, the lawyer must inform the client of them. ${ }^{17}$ In all cases of contemplated perjury, the lawyer shall warn the client. against pursuing that course. ${ }^{18}$ The lawyer is specifically forbidden to aid the client in "contriving false testimony." 19 The lawyer must withdraw from representing the client if the client nonetheless insists on presenting the perjury. ${ }^{20}$ These rules are the same for criminal cases unless "applicable law" compels a different standard of conduct. ${ }^{21}$

In general, then, under the Kutak Commission draft undisclosed perjury will be presented by a client only when the lawyer is violating professional duties, when the lawyer has a reasonable doubt about the perjurious nature of the testimony and elects to present the evidence, when the "client" is not represented by counsel, or when the client is a defendant in a criminal case in a jurisdiction whose constitutional law forbids defense counsel from disclosing client perjury.

\section{The Freedman-ATLA Draft}

The Freedman-ATLA draft was motivated in large part by concern about the extent to which the Kutak Commission was proposing to compromise client confidentiality. ${ }^{22}$ But it differs from the Kutak Commission proposal only in certain

15. Kutak-ABA proposal, Rule 3.1(a)(3). A further provision in the same rule is that the lawyer may not "offer without suitable explanation evidence that the lawyer knows is substantially misleading."

16. Id., Rule 3.1(b).

17. See id., Rule 1.4(b); id., Comment, Ethical limitations, at 14.

18. See $i d$., Rule 2.4 and Comment.

19. Id., Rule 2.3(a)(2).

20. Cf. id., Rule 1.16(a)(1); Comment, Mandatory withdrawal, at 51; Comment, Appointed counsel, at 49 . The Kutak-ABA draft states the mandatory withdrawal obligation in a needlessly obscure way. See infra at note 37.

21. See id., Rule 3.1(f)(2) and (3). The "applicable law" refers to doubts about the constitutionality of these courses of action in criminal cases in light of possible due process and right to counsel requirements. See $i d$., Comment, at 66.

22. See Koskoff, supra note 9. Freedman had been invited to participate in general public discussions on confidential drafts of early versions of the Kutak Commission on client perjury at the August 1979 meeting of the ABA. His denunciation of any disclosure requirement was well publicized, as was the "leak" of the text of the Commission's until then confidential draft. See, e.g., Jonathon M. Winer, Radical Proposals Unveiled After 2-Year Study-Ethics Draft Ignites Uproar, Nat'l L.J., Aug. 27, 1979, at 1, col. 1; 48 U.S.L.W. 2152 (Aug. 28, 1979); Monroe H. Freedman, Ethics and Confidentiality (letter to editor), Nat'l L.J., Sept. 10, 1979, at 14, col. 3; The Ethics of Secrecy (editorial), Nat'l. L.J., Sept. 3, 1979, at 16, col. 1. The "leaked" confidential draft was 
respects. In language that substantially tracks the Kutak Commission, the Freedman-ATLA draft provides that if a client announces the intention to commit perjury, the client's lawyer shall not "knowingly" 23 "present materially false evidence." ${ }^{24}$ Under Rule $6.6,{ }^{25}$ if the client announces an intent to commit perjury, the lawyer is required to withdraw, unless withdrawal would result in direct or indirect divulgence of a client confidence. ${ }^{26}$ Where withdrawal is not available-for example, when the client announces the intention to commit perjury during the trial-the lawyer must stay in the case, present and argue the perjury in the same manner as the lawyer would if it were accurate, and not disclose its perjured nature in any way. ${ }^{27}$ It is not clear from the Freedman-ATLA draft whether the attorney is under any obligation to attempt to dissuade the client from presenting perjured testimony. ${ }^{28}$ Virtually no distinction is recognized for civil and criminal cases. ${ }^{29}$ To the extent that an attorney is thus permitted (indeed, required) by the Freedman-ATLA draft knowingly to participate without disclosure in the presentation of perjured testimony in some civil cases, the proposal is virtually unprecedented. ${ }^{30}$

\section{Areas of Agreement}

Despite the sharpness of their differences, the Freedman and Kutak drafts

widely printed in the legal press. E.g., The Record: Text of Initial Draft of Ethics Code Rewrite Committee, Legal Times of Washington, Aug. 27, 1979, at 26, col. 1; BNA Daily Report to Executives, Special Supplement to Release No. 46 (Aug. 21, 1979).

23. See Freedman-ATLA proposal, at 8-9 for its definition of "knowing."

24. Id., Rule 3.7.

25. This is unequivocally clarified under Freedman-ATLA proposal, Comment, at 603-4. See also id., Illustrative Cases 6(a), 1(j).

26. And an "indirect" divulgence may be authorized, although not required, in a case where the client has deceived the lawyer about the intent to commit perjury. See infra at note 29.

27. See Freedman-ATLA proposal, Rule 1.2; id., Illustrative Cases 1(a), 1(b), 1(c), 1(i), and 1(j).

28. Cf. $i d$., Comment, at 104 (describing the practice of "advising clients that a particular course of conduct should not be followed on grounds of legality or morality"). Because of the importance attached to avoiding withdrawal (see id., Comment, at 603-4), it would seem necessary at least that the client be warned of the attorney's obligation to withdraw if the client persists in demanding to present perjury. See infra note 38 .

29. A curious, and unclear, distinction between civil and criminal cases is contained in FreedmanATLA proposal, Rule 6.5. This provides that "in any matter other than criminal litigation, a lawyer may withdraw from representing a client if the lawyer comes to know that the client has knowingly induced the lawyer to take the case or to take action on behalf of the client on the basis of material misrepresentations about the facts of the case, and if withdrawal can be accomplished without a direct violation of confidentiality" (emphasis added). This is elaborated upon in id., Comment, at 603 , at a point immediately preceding a discussion of mandatory withdrawal when feasible and when a client intends to commit perjury: "It should also be noted that Rule 6.5 allows indirect divulgence of confidences by withdrawal from a class of cases also covered by Rule 6.6 [the rule under which intended-perjury withdrawal is mandated], those noncriminal matters where the client has knowingly induced the lawyer either to take the case, or to take action on the client's behalf, on the basis of material factual misrepresentations" (emphasis added).

As applied to client perjury, this would appear to mean that a lawyer in a civil case may (but is not required to) withdraw, even if this will indirectly reveal to opposing counsel or to the fact-finder (if a judge) that the client is committing perjury, if the client also, initially, deceived the lawyer with the same perjury. Deception of one's own lawyer, even if later corrected, is thus exalted over deception of any other person or institution. This supplies discretionary self-protective cover for the same lawyer who, at least under one Freedman-ATLA version (Alternative B), would not even be required to reveal a clear and present client intent to murder an identified third party victim (cf. id., Illustrative Case $1(\mathrm{~g}))$.

30. See text at note 77 infra. 
agree on several fundamental matters. First, each proposal treats client perjury as a matter appropriate for detailed and precise regulation in a system of attorney discipline. This is "law" and not a matter only of "ethics" or "discretion." And no longer is client perjury a matter to be left to the interpretation of obscurely worded regulations. ${ }^{31}$ The Freedman-ATLA draft explicitly would discipline a lawyer for failing to support a client's effort to commit perjury in any civil or criminal case in which withdrawal without divulgence is not possible; ${ }^{32}$ the Kutak-ABA draft would discipline a lawyer who did so. ${ }^{33}$ Second, each treats the matter of client perjury as a real and recurring, not an imagined, problem in the administration of the adversary system. ${ }^{34}$

Quite beyond these important congruences on matters of general approach, there are fundamental areas of agreement with respect to specific courses of lawyer conduct that are prescribed. Each draft is willing to assume that in a significant number of cases the lawyer will have a sufficient degree of certainty about the truth or falsity of testimony to make it relevant to require a specific course of conduct on the part of the lawyer. ${ }^{35}$ Indeed, the Freedman-ATLA draft, with its lower threshold definition of "reasonably certain" will create mandatory obligations to counter client perjury more often than would the Kutak Commission draft. ${ }^{36}$

31. A persistent criticism of the existing Code of Professional Responsibility has been that it deals with the problem of client perjury in a confusing, obscure, and convoluted manner. See, e.g., Charles W. Wolfram, Client Perjury, 50 S. Cal. L. Rev. 809, 819-22 (1977); Victor H. Kramer, Clients' Frauds and Their Lawyers' Obligations: A Study in Professional Irresponsibility, 67 Geo. L.J. 991 (1979); Comment, The Failure of Situation-oriented Professional Rules to Guide Conduct: Conflicting Responsibilities of the Criminal Defense Attorney Whose Client Commits or Intends to Commit Perjury, 55 Wash. L. Rev. 211 (1979).

32. Freedman-ATLA proposal, Illustrative Case 1(i).

33. Kutak-ABA proposal, Rules 3.1(a)(3), 3.1(b).

34. Id., Comment, at 61-66, 67-68; Freedman-ATLA proposal, at 106.

To the extent that perjured testimony is presented through a government lawyer, such as the prosecutor in a criminal case, both proposals agree that the disclosure requirement is quite strict. See Kutak-ABA proposal, Rule 3.10(d) (prosecutor has duty to seek all evidence, whether or not favorable to accused, and to make "timely disclosure to the defense of all evidence supporting innocence or mitigating the offense"); Freedman-ATLA proposal, Rule 9.7 (prosecutor shall volunteer to the defense "any information that the prosecutor knows is likely to be useful to the defense"). Even more broadly, the Freedman-ATLA proposal would require any lawyer representing the government in court to "inform the tribunal of any facts or legal authorities that might materially affect the decision in the case, and that have not been brought to the attention of the tribunal by other counsel." Id., Rule 9.10. Compare Kutak-ABA proposal, Rule 3.1(c) (mandatory disclosure of legal authority in all cases for all lawyers); Rule 3.1(e) (discretion in all cases to disclose evidence favorable to other side).

35. See Kutak-ABA proposal, Rule 3.1(a)(3) (evidence falsity must be such that the "lawyer is convinced beyond a reasonable doubt"') (emphasis added). If the lawyer's conviction is less than that, a further provision permits, but does not require, refusal to participate in offering the evidence. Id., Rule 3.1(e) ("evidence that the lawyer believes with substantial reason to be false") (emphasis added). The required state of attorney knowledge is somewhat confusingly referred to in the Kutak Commission Comments in terms of what is "known," the lawyer's being "satisfied" the evidence is false, the necessity for a "reasonable investigation" to clarify its status, and whether falsity is "quite clear." See id., Comment, at 63.

36. The Freedman-ATLA proposal contains an extensive Introductory Comment defining "knowingly." See Freedman-ATLA proposal at 8-9. The "convinced beyond a reasonable doubt" standard of the Kutak Commission that is explicitly applicable to client perjury is apparently less inclusive than the Freedman-ATLA definition of "knowingly": "As used herein, a lawyer knows certain facts, or acts knowingly or with knowledge of facts, when a person with that lawyer's professional training and experience would be reasonably certain of those facts in view of all the circumstances of which 
But by far the most important point of agreement is that both proposals require that the lawyer withdraw from the representation in any civil or criminal case if the client insists on presenting perjured testimony. The mandatory withdrawal rules are tempered differently in each proposal. Nonetheless, both will compel attorneys in a great many cases to withdraw unless they can convince their clients to tell the truth. Both proposals are somewhat ill drafted with respect to this point. The wording and arrangement of the Kutak Commission draft is unnecessarily obscure ${ }^{37}$ The Freedman-ATLA proposal is both confusing and possibly misleading. ${ }^{38}$

Given the mandatory withdrawal requirement that both proposed sets adopt,

the lawyer is aware." Freedman-ATLA proposal, at 9 (emphasis added). Unlike the Kutak-ABA proposal, no duty to investigate or inquire is implied; but "a studied rejection of reasonable inferences is inadequate to avoid ethical responsibility." Id. The same comment at an earlier point specifically rejected arguments that a lawyer does not often "know" that a client's testimony is perjured. Id. at 8.

37. The Kutak-ABA proposal does not mention mandatory withdrawal at any point in its rules or commentary on client perjury. Cf. Kutak-ABA proposal, Comment, at 64 (mention of whether attorney whose client intends to commit perjury is "able" to withdraw). But id., Rule 1.16(a)(1) on mandatory withdrawal provides that, unless a court forbids it, a lawyer "shall withdraw" if "continuing the representation will result in a course of conduct by the lawyer that is illegal or inconsistent with the rules of professional conduct." Then, under the heading of "Mandatory withdrawal," $i d$., Comment, at 51, the need for court approval for withdrawal in a court-appointed case is discussed in these terms:

Difficulty may be encountered if withdrawal is based on the client's demand that the lawyer engage in unprofessional conduct, such as the presentation of perjured testimony. The court may wish an explanation for the withdrawal, while the lawyer is bound to keep confidential the facts that would constitute such an explanation. The lawyer's statement that professional considerations require termination of the representation ordinarily should be accepted as sufficient.

This strongly implies that withdrawal is mandatory in all civil and criminal cases in which the client demands that the lawyer present perjured testimony.

Integration and clarification of the Kutak Commission's treatment of client perjury and mandatory withdrawal obviously seems desirable. In the first place, if withdrawal is mandatory when a client insists on presenting perjured testimony, this should be made more explicit than is stated in the present Rule and Comment. As Rule 1.16(a)(1) is presently drafted, it is not clear why withdrawal is required under it when the client "demand[s] that the lawyer engage in unprofessional conduct, such as the presentation of perjured testimony." (Id., Comment, at 51.) The demand presumably will not be availing because of the lawyer's duty under the antiperjury rules to refuse to participate in it and, if perjury nonetheless is presented, to rectify it through disclosure. The duty could be clarified by adding at the end of Rule 1.16(a)(1) the words "or the client insists that the lawyer engage in such a course of conduct." In the second place, the rules on mandatory withdrawal should be explicitly referenced in the Comment on client perjury under Rule 3.1. It should also be clarified to what extent the disclosure/rectification rules still apply after effective withdrawal.

38. The matter of withdrawal is mentioned only in a general way in the Freedman-ATLA Comment on confidentiality and it somewhat misleadingly fails to mention the mandatory withdrawal rule for client perjury cases. See, id., Comment, at 106 ("Also, withdrawal is permitted in non-criminal cases, even when a confidence might thereby be divulged indirectly, when the client has induced the lawyer to act through material misrepresentation (Rule 6.5)"'). A rule other than that mentioned in the confidentiality comment-Rule 6.6 as interpreted in Comment, at 603-4-is explicitly stated to require withdrawal so long as no divulgence of a client confidence would result. Rule 6.6 provides: "A lawyer shall decline or withdraw from representing a client when such action is necessary to avoid commission by the lawyer of a disciplinary violation, unless such action would result in a violation of Rule 1.2, proscribing direct or indirect divulgence of a client's confidences." This is interpreted as follows in the Comment, id., at 603-4: "A lawyer is forbidden by Rule 3.7 to knowingly present false evidence. Therefore, withdrawal from representation would be required by Rule 6.6 when the lawyer knows through a confidence that the client intends to present false evidence, and when withdrawal would not result in violating a confidence. When the lawyer's refusal to present false evidence would result in violating a confidence, however, Rules 1.2, 3.7, and 6.6 require the lawyer to continue in the case." 
in practice the more radical aspect of the Freedman-ATLA proposal for lawyer participation in client perjury may have a much diminished impact. In the vast majority of civil cases that are competently prepared prior to the filing of suit, a lawyer under the Freedman-ATLA standard would already be on notice of the client's version of the facts and, accordingly, of the client's intent to commit perjury. In these circumstances, the lawyer would be required either to convince the client to testify truthfully or to withdraw, presumably after warning the client that withdrawal was mandatory unless the client agreed to testify truthfully. ${ }^{39}$ The only civil cases under the Freedman-ATLA proposal in which a lawyer would not be required to withdraw-and then would be required to present undisclosed false client testimony-would be those in which the client's intent to commit perjury was not manifested until such a late time that withdrawal could not be achieved without "direct or indirect" disclosure of the perjury. And these presumably would largely be the rare civil cases in which a reason would have to be assigned for the withdrawal. Defense representation in criminal cases typically is handled differently by trial courts: they are quite reluctant to permit withdrawal once an appearance has been entered unless a compelling reason is given. Under these circumstances it is apparent that in practice the chief area of practical difference between the Kutak-ABA and Freedman-ATLA proposals is that of criminal defense representation. And even in criminal defense work, a lawyer under the Freedman-ATLA draft would be required to reject or withdraw from a private-retainer representation if the client's intent to commit perjury were reasonably certain prior to the entry of an appearance by that attorney.

\section{Areas of Disagreement}

Thus those instances in which a lawyer could not withdraw from the representation without divulging a confidence of the client are treated very differently in the Kutak-ABA and Freedman-ATLA proposals. In these instances the obligations of the lawyer that have traditionally been discussed by cases and commentators are those relating to the following: "remonstrating" with the client in an attempt to convince the client to correct or not to commit the perjury; calling as a witness a client who has announced the intention to commit perjury; examining the client as a witness when it is known that further answers will be perjured; arguing to the fact-finder the credibility of the client's perjured testimony; and, particularly in the case of surprise perjury, affirmatively disclosing the perjury to the court and/or the affected party in order to rectify it.

Regarding each of these elements, the drafts differ and often conflict in all civil cases and, to the extent that constitutional law will not supply a uniform solution, in criminal cases as well.

\section{Remonstration}

Confronting the client to urge that perjury not be given or that prior perjury be corrected is specifically required by the Kutak-ABA proposal. ${ }^{40}$ In fact, the at-

39. Presumably an attorney's violation of the Freedman-ATLA obligation to withdraw would not be remitted by the fact that the lawyer's failure to withdraw continues until so late that withdrawal without divulgence was no longer available.

40. See Kutak-ABA proposal, Comment, at 63-64 (civil case), 64-66 (criminal defense). 
torney is encouraged to explain this limitation on his or her representation at the outset of the relationship. ${ }^{41}$ The Freedman-ATLA draft is entirely silent on the matter, perhaps by way of oversight. ${ }^{42}$ In view of the possibility of a prosecution for perjury, it would seem that the Freedman-ATLA general standard of competence ${ }^{43}$ would require an attorney at least to confront the client with information about the legal hazards involved in presenting perjury.

\section{Access to Witness Stand}

The question of calling as a witness a client who will commit perjury is not dealt with unequivocally by either proposal. If the matter is not controlled by constitutional law (and it almost certainly would not be in the civil context), ${ }^{44}$ it might be thought that the general Kutak-ABA rule on client autonomy ${ }^{45}$ would require the lawyer to accede to the client's wish to take the stand. But in view of the mandate in the same rule that a lawyer not pursue a course of conduct that is either illegal or in violation of a rule of professional conduct, ${ }^{46}$ it seems evident that a lawyer would be prohibited by the Kutak-ABA draft from calling a perjurious client as a witness.

The Freedman-ATLA draft is similarly quite opaque on the matter. In view of its very broad Rule 3.7 that a lawyer may not "present" false evidence, an obligation not to call the perjurious client as a witness may also be intended. ${ }^{47}$

41. See id., Rule 1.4(b); id., Comment, at 14.

42. Freedman has previously asserted that a lawyer should attempt to persuade a client not to present perjured testimony. See Freedman, Lawyers' Ethics in an Adversary System, supra note 11, at $28,29,31$. As a matter of competence, an attorney may also be required to warn a client that perjury is a crime. See note 28 supra.

Under the ATLA proposal, suppose that a client in a civil case proposes to commit perjury by telling a false story in a quite implausible way (and assume further that withdrawal would divulge a client confidence). Competent representation, it may be thought, would require that the lawyer advise the client that the story would be regarded as implausible by the jury. May the lawyer do so? May-or must - the lawyer, if requested by the client (or perhaps if not requested), inform the client of other, better ways to tell the lie? Freedman-ATLA proposal, Rule 3.6, which seems not to be the subject of any commentary or illustration, states: "A lawyer shall not knowingly participate in creating perjured testimony, other false evidence, or a misrepresentation upon which another person is likely to rely and suffer material detriment." It is utterly unclear whether this would subject to discipline a lawyer who informs the client that the proposed lie is implausible or who goes further and "coaches" the client on a still perjured, but more plausible, story. In addition to the Freedman-ATLA rules and comments dealing specifically with perjury, compare id., Rule 3.2 ("A lawyer shall fully inform the client of a client's rights and possible courses of conduct regarding issues of substantial importance to the client, except . . . as provided in Rule 3.3") and Rule 3.3 ("A lawyer shall not advise a client about the law when the lawyer knows that the client is requesting the advice for an unlawful purpose likely to cause death or serious physical injury to another person'). The integration of these rules with, particularly, id., Rule 3.6 is quite unclear in the context of the problem of preparing a client for future perjured testimony.

43. Id., Rules 4.1-4.7.

44. The right of the accused effectively to take the stand to testify perjuriously over the wishes of defense counsel has not been settled by the Supreme Court. See infra at note 76.

45. Kutak-ABA proposal, Rule 1.3.

46. Id., Rule 1.3(b). The rule violated would be Rule 3.1(a)(3).

47. A contrary position may be implied by Freedman-ATLA proposal, Illustrative Case 1(j), which states that it is not a disciplinary violation for a lawyer to present "in the ordinary manner" client testimony known in advance to be perjured. The illustration could be limited, although not with a great range of remaining applicability, to situations in which failure to call the client as a witness would divulge a confidence-for example, where the lawyer had already announced the intention to call the client as a witness before the client's intent to commit perjury was revealed to the lawyer. 
The answer to the question is, obviously, of pivotal importance because a lawyer's power to keep off the stand a client who intends to commit perjury may leave only the "surprise perjury" cases for different treatment under the two proposals.

\section{Examination of Witness}

The Kutak-ABA draft presumably would not permit a lawyer to ask a question if the lawyer knows that the client's response will be perjured. ${ }^{48}$ In contrast, the Freedman-ATLA draft would require the lawyer to ask the question under such circumstances if the lawyer's failure to do so would result in divulgence of a client confidence. ${ }^{49}$ It is entirely unclear from the Freedman-ATLA proposal how these circumstances of threatened "divulgence" would be defined, with what degree of probability the possibility of divulgence must appear, whether the threatened divulgence would be only of a central issue or of some lesser or peripheral matter, and the extent to which the impending divulgence would impair the interests of the client (is mere embarrassment sufficient, or is loss of a claim or defense or some other dire consequence required?). In the present, opentextured expression of the Freedman-ATLA draft, it appears very unlikely that a literal-minded discipline committee could ever find a violation, regardless of which course an attorney took. And because "divulgence" is critical to withdrawal, to calling the client as a witness, and, as will be seen, to summation, it may be that the effect of this very loose criterion is to remove lawyer participation in client perjury from the effective area of disciplinary regulation.

\section{Summation}

Arguing to the fact-finder the credibility of client testimony known to be perjured would presumably be a disciplinary violation under the Kutak-ABA proposal for reasons similar to those involved in asking a client a question that the lawyer knows will be answered by perjury. ${ }^{50}$ Contrarily, it is clear under the Freedman-ATLA draft that if failure to so argue would result in divulgence of a client confidence the argument would be required. ${ }^{\text {st }}$

\section{Disclosure}

The Kutak-ABA proposal explicitly requires the lawyer to disclose past client perjury in order to rectify its consequences. ${ }^{32}$ In all civil cases, and in criminal

48. This is stated nowhere in the draft, but any other rule would be nonsensical in light of the clearly stated obligation to reveal client perjury. Kutak-ABA proposal, Rule 3.1(b). A rule against asking such a question was probably thought to be within the prohibition in Rule 3.1(a)(3) against an "offer" of evidence known to be false.

49. See Freedman-ATLA proposal, Illustrative Cases 1(i), 1(i).

50. See supra at note 48.

51. Most in point appears to be Freedman-ATLA proposal, Illustrative Case 1(i), which is transparently an explicit rejection of the approach recommended in $\S 7.7(\mathrm{c})$ of the $A B A$ 's Defense Function Standards. See American Bar Association, Special Committee on Standards for the Administration of Criminal Justice, Standards Relating to the Prosecution Function and the Defense Function, at Defense Function § 7.7(c) (Approved Draft Chicago: American Bar Association, 1971). After setting out a factual situation that tracks the procedure in $\$ 7.7$ (c), the Illustrative Case 1(i) concludes that the lawyer, in the manner of final argument, has committed a disciplinary violation.

52. Kutak-ABA proposal, Rule 3.1(b). Disclosure of perjury for a purpose other than to rectify its 
cases to the extent not constrained by applicable law, the lawyer who later discovers client perjury (or perjury by any other witness) "shall disclose that fact and take suitable measures to rectify the consequences, even if doing so requires disclosure of a confidence of the client or disclosure that the client is implicated in the falsification." 53 In direct contrast, the Freedman-ATLA draft under all circumstances explicitly forbids a lawyer from disclosing past client perjury. ${ }^{54}$ In sum, when a lawyer has not been able to prevent client perjury-surprise perjury being a common illustration-disclosure would be required by the Kutak-ABA proposal and forbidden by the Freedman-ATLA draft.

\section{Client Perjury-The Choices}

The differences between the Kutak-ABA proposal and that of the FreedmanATLA group emerge from more than 15 years of increasing attention to the problem of client perjury by academic commentators, courts, and professional groups. ${ }^{35}$ Most who have studied the problem agree that the ABA's Code of Professional Responsibility, promulgated in 1969 after the matter had been much discussed, dealt with client perjury in an unclear, confusing, and unsatisfactory way. ${ }^{36}$ The general difficulty with the Code is that at different places it seems to give primacy to the protection of the truth-seeking objectives of trials (DR 7-102(A)(4), (A)(6), and (A)(7)) and, contrarily, to the protection of client confidences (DR 4-101(B)(1) and DR 7-102(B)(1), as amended). ${ }^{57}$ But the simple truth is that in most instances of client perjury both objectives cannot be served adequately. Particularly in the case of surprise perjury in the heat of trial, lawyers

effect in the immediate case has not been required by any case that has been found. It has been argued for by one commentator. See Dan Aaron Polster, The Dilemma of the Perjurious Defendant: Resolution, Not Avoidance, 28 Case W. Res. L. Rev. 3, 34 (1977) (lawyer should warn client that lawyer "would be a chief witness in the client's subsequent perjury trial"). Contra, Robert P. Lawry, Lying, Confidentiality, and the Adversary System of Justice, 1977 Utah L. Rev. 653, 678-80.

53. Kutak-ABA proposal, Rule 3.1(b). While nowhere mentioned explicitly, it appears that the sense of the rule would not require disclosure if the perjured testimony-for example, from a turncoat witness-is disadvantageous to the lawyer's client.

54. Freedman-ATLA proposal, Rule 1.2; id., Illustrative Case 1(b) (factually this appears very similar to Committee on Professional Ethics v. Crary, 245 N.W.2d 298 (Iowa 1976); the result, however, is contrary). An example of prohibited indirect disclosure is given in Freedman-ALTA proposal, Illustrative Case 1(j).

55. The major authorities are collected in the References to the Kutak-ABA proposal, Comment, at 68. Among others, the following major treatments of the problem have appeared since the KutakABA references were apparently collected: Wayne D. Brazil, Unanticipated Client Perjury and the Collision of Rules of Ethics, Evidence, and Constitutional Law, 44 Mo. L. Rev. 601 (1979); Kramer, supra note 31; Comment, supra note 31.

Philosophers have also contributed significantly to an understanding of the problem of lawyer representation of clients who commit perjury. See, e.g., Sissela Bok, Lying: Moral Choice in Public and Private Life, 146-64 (New York: Pantheon Books, 1978).

56. See authorities cited in note 31 supra.

57. The 1974 amendment to DR 7-102(B)(1) excepted from its requirement that a lawyer disclose a client's "fraud upon a person or tribunal" those instances where the lawyer's information came through a "privileged communication." The ABA ethics committee subsequently interpreted this exception in a very expansive way. ABA Formal Opinion 341 (Sept. 30, 1975), in American Bar Association, Committee on Ethics and Professional Responsibility, Recent Ethics Opinions, Sept. 30, 1975 [looseleaf]. With the disclosure requirement of DR 7-102(B)(1) thus rendered virtually inoperative, the remaining applicable rule is DR 4-101(B)(1) which prohibits a lawyer from disclosing any client confidence or secret. 
should be directed clearly and unequivocally to act in a manner that will serve one or the other objective-or possibly, a clear rule could reflect some kind of compromise of these values reminiscent of the ABA's Defense Function Standards. ${ }^{58}$

Two things might have flawed treatment of the problem of client perjury in the ABA's current Code of Professional Responsibility. First, the Code drafters might have overlooked the fact that they were not writing on a clean legal slate. Any code of lawyer conduct that is to be given the force of law through its coercive use against attorneys in disciplinary proceedings must in some way be made compatible with law in adjacent areas stemming from constitutional requirements and rights, statutory and common law, and court rules. For example, it would be unintelligible for any American jurisdiction to adopt a rule of professional discipline prohibiting a lawyer from disclosing client perjury if the common law of that jurisdiction would hold the same lawyer liable for damages to a person directly injured because of the lawyer's participation in the client's perjury or would subject the lawyer to prosecution for subornation of perjury. ${ }^{s 9}$ To impose such impossibly conflicting duties on attorneys is indefensible. It seems an inappropriate method of lawmaking either to repeal statutory and common law rules silently through adopting rules of lawyer discipline or to adopt professional rules that are not intended to be enforced because of their collision with other overriding legal rules.

Second, the drafters and promulgators of the $\mathrm{ABA}$ Code were all lawyers writing rules for lawyers. Several commentators have wondered aloud whether this self-regulation does not at critical points give rise to a preoccupation with parochial lawyer concerns and interests to the detriment of broader social concerns. ${ }^{60}$ For example, some nonlawyers might view a rule against disclosure of

58. See American Bar Association Project, supra note 51, at Defense Function § 7.7(c). The Defense Function solution has not found wide acceptance. Basically, it requires the criminal defense lawyer confronted with client perjury to put the client under open narrative and not ask specific questions or argue the credibility of the client's perjured testimony in summation. But the Standards forbid the lawyer to disclose the client's perjury. Why judges, all of whom were urged to become familiar with the Standards, would remain in doubt about the lawyer's disbelief of the client's testimony when given under this rare rubric was unexplained. And defense attorneys were not told how to proceed in the event that the prosecutor successfully objected to the open narrative form of testimony. See Wolfram, supra note 31, at 824-27.

59. If the facts were available to sustain it, a valid claim could be stated in many jurisdictions for the recovery of damages against an attorney who knowingly participates in the presentation of perjured testimony. Cf. Scavello v. Scott, 549 P.2d 1337 (Colo. App. 1976); Meier v. Peariman, 401 N.E.2d 31, 40-41 (Ind. App. 1980); McDonald v. Stewart, 289 Minn. 35, 182 N.W.2d 437, 440 (1970) (dictum in each case: facts in cases do not support finding of knowing attorney participation). At least Colorado and Minnesota have adopted the amendment to DR 7-102(B)(1) that removes the permission for disclosure of client perjury. Similarly, it is unclear to what extent an attorney who knowingly elicits perjured testimony is susceptible to the criminal charge of subornation of perjury. See authorities cited in Wolfram, supra note 31, at 816-17 n.23. Cf. Office of Disciplinary Counsel v. Pileggi, $570 \mathrm{~F} .2 \mathrm{~d} 480$ (3d Cir. 1978) (per curiam) (discipline of attorney convicted of subornation of perjury of client despite belief that informing court would betray client's confidence).

60. E.g., Thomas D. Morgan, The Evolving Concept of Professional Responsibility, 90 Harv. L. Rev. 702 (1977); Charles W. Wolfram, Barriers to Effective Public Participation in Regulation of the Legal Profession, 62 Minn. L. Rev. 619, 634-36 (1978). A recently funded research project of the Rand Corporation will study the ability of the legal profession to regulate itself effectively. See Edward J. Burke, Insurance Industry Role Raises Issue of Bias-Rand Unit to Examine Civil Justice, Nat'l L.J., Mar. 17, 1980, at 4, col. 2. 
client perjury as primarily designed to make the role of the lawyer more comfortable, and the lawyer's participation in the adversary system more fun and profitable. The appeal of win-at-any-cost litigator macho may allure some members of the profession, but the likelihood that it would prove attractive to many members of the public concerned about the corrupting influence of perjury in trials can readily be doubted. Difficult choices must be made in redrafting the Code, and consideration of them should be fully reflective of the range of related legal interests and social concerns that lawyer participation in client perjury raises. The necessity to confront these choices, and these problems in making them, is inevitable for both the ABA and ATLA groups. Whether the process by which these groups will reach their own decisions permits confidence that broad, nonprofessional public interests are in the final analysis taken seriously into account remains an open question. ${ }^{61}$

The choice to be made in drafting rules of professional responsibility about client perjury is a choice between the value of accurate factual determinations in the system of adjudication and the value of client confidentiality.

Few would deny that unfalsified testimony is an important means to the objective of providing the fact-finder with the opportunity to make an accurate assessment of past facts and thereby to provide a sure basis for the nonarbitrary imposition of community standards. Few would wish any longer to maintain that the adjudicative process works mechanically in this fashion, but most would hope that it can be kept working optimally to achieve this objective of accuracy and, through accuracy, fairness. The point is a plain and simple one, although subject to useful elaboration, and it obviously moved the drafters of both the Kutak-ABA ${ }^{62}$ and the Freedman-ATLA ${ }^{63}$ proposals.

As a consequence, important values and interests support arguments against lawyer participation in client perjury. Such participation could mean that perjury would often be accepted as truth and could not be dislodged through crossexamination or other forms of rebuttal. ${ }^{64}$ Opposing parties would face the prospect of unjust defeat in litigation and might be sorely tempted to enhance their own case with their own exaggerated or entirely falsified version of the facts. In the process, jurors either would erroneously accept false testimony as factual or if forewarned about the possibility of being influenced by perjured testimony from both sides, ${ }^{65}$ would attempt to reach decisions through private appraisals or investigations of the facts, by arbitrary hunches, or by perverse values that were neither litigated nor accepted by the legal system. ${ }^{66}$ The result could be a

61. The atra Commission included nonlawyer members (see Freedman-ATLA proposal, at v.); the Kutak Commission had one. While nonlawyers have been appointed with some regularity to lawyer discipline boards (see More States Adding Public to Discipline Boards, Nat'l L.J.,June 25, 1979, at 7 , col. 1 (public participation in 23 states)), the public still seems largely excluded from effective decision-making roles in the development of lawyer codes. See Wolfram, supra note 60.

62. Kutak-ABA proposal, Comment, at 62-64.

63. Freedman-ATLA proposal, Preamble, at 5-6.

64. See Wolfram, supra note 31 , at 813 n.14.

65. Critics of proposals for some forms of attorney participation in client perjury have urged that if such a role were permitted the jury should be informed that lawyers were under no obligation to prevent perjury so that the jury could more fully assess the credibility of witnesses. See, e.g., Abraham P. Ordover, The Lawyer as Liar, 2 Am. J. Trial Advocacy 305, 315-317 (1979).

66. E.g., the police don't arrest people who aren't guilty; pushy big-city people are always trying 
dangerous decrease in public willingness to accept judgments issued by the adversary system as a fit means for settling controversies.

But, important as it is, accuracy is an instrumental value, not an absolute principle, of adjudication. The failure to find truth is sometimes accepted in the legal system in the service of a value deemed, at least on that occasion, to be higher. The clearest case is the refusal to permit reprosecution of an acquitted person who can plainly be shown to have committed perjury during the trial.67 Even the accused who announces while leaving the courthouse with a judgment of acquittal of a murder charge that his or her own lies on the witness stand got them off cannot be retried for the same offense. Moreover, it is impermissible to charge an acquitted person even with the crime of perjury for any part of that person's testimony that related to the elements of the charge on which the acquittal was obtained. ${ }^{68}$ And in the civil area, most jurisdictions prohibit suits for libel, malicious prosecution, or similar torts where the foundation of the suit is the alleged commission of perjury by the defendant in prior litigation which led to a judgment against the present plaintiff. ${ }^{69}$ The values of finality in litigation-and peace for those released by a judgment from entoilment in it-are in these instances thought to override the interest in finding the truth.

Specifically with respect to the question of attorney participation in client perjury, the principal arguments for reluctantly displacing the value of accuracy in adjudication relate to the collective interests of individual litigants. These arguments are fittingly grouped by the Kutak-ABA ${ }^{70}$ and Freedman-ATLA ${ }^{71}$ discussions under the heading of client confidentiality. Essentially, the argument is that if an attorney were required (or perhaps, even permitted) to reveal client perjury, this would unduly chill the willingness of too many clients to confide in their attorneys their knowledge of matters that, perhaps mistakenly, they might regard as embarrassing, illegal, dangerous, or irrelevant. ${ }^{72}$ Unless attorneys are able to assure clients that nothing they reveal to them will be used against their interests, it

to rip off insurance companies; I never met a Welshman who wasn't a thief; lawyers help other people to lie so why should anybody believe them when they testify themselves; etc.

The deterioration of the jury function because of jurors' awareness of lawyer cooperation in the presentation of perjury has been cited as an argument against such lawyer conduct. E.g., Bok, supra note 55, at 163; Ordover, supra note 65. Social scientists report that subjects of social science experiments have shown an increasing tendency to suspect that experimenters will employ deception, and they react to their belief of deception in a way that makes the experiment results potentially quite misleading. See Edward Diener \& Rick Crandall, Ethics in Social and Behavioral Research 82-84 (Chicago: University of Chicago Press, 1978).

67. The double jeopardy clause would prevent the retrial. U.S. Const. Amend. V.

68. See generally Annot., 89 A.L.R.3d 1098 (1979). Cf. Ashe v. Swenson, 397 U.S. 436 (1970) (applicability to states of constitutionally based doctrine of collateral estoppel in criminal case).

69. E.g., Smith v. Sinclair, 424 F. Supp. 1108 (W.D. Okla. 1976); Reagan v. Guardian Life Ins. Co., 140 Tex. 915, 166 S.W.2d 909 (1942); see generally 60 Am. Jur. 2d, Perjury $§ 75$ (Rochester, N.Y.: Lawyers Co-operative Publishing Co., 1972).

70. Kutak-ABA proposal, Comment, at 22-23.

71. Freedman-ATLA proposal, Comment, at 104-7.

72. These considerations underlie both the attorney-client testimonial privilege and the broader rule of professional conduct that protects against disclosing a great amount of information that is not covered by the narrower testimonial privilege. See Kutak-ABA proposal, Rule 1.7(a); FreedmanATLA proposal, Comment, 104-5. The Freedman-ATLA Comment, id., is rather vague about the intended reach of a "confidence" but it is apparently extremely broad: "any information obtained by the lawyer in the course of the lawyer-client relationship." 
is feared that much that should be revealed will remain unknown to the lawyer. One form of the argument makes this claim in the interest of all litigants, whether deserving of victory in the forthcoming trial or not. A more appealing form claims this interest for those who are deserving of victory but are victims of circumstances or of their own ignorance about the law and the workings of the legal system. Either argument can thus claim that complete confidentiality in the end is better calculated in more cases to lead to truth.

Criminal defense cases have formed a special class in which lawyer participation in client perjury may be more defensible. This is primarily because of constitutional arguments concerning the right to the effective assistance of counsel, the due process right to a trial before an unbiased fact-finder, and the right against self-incrimination. In essence, the effective assistance argument is that a lawyer who refuses to assist the accused to present perjured testimony unduly interferes with the rendition of other essential legal services. ${ }^{73}$ The due process argument is that the accused whose attorney has disclosed his or her perjury could not thereafter obtain a fair trial from a fact-finder subjected to the disclosure. ${ }^{74}$ The self-incrimination argument is that a lawyer who reveals a former statement of an accused given in confidence violates constitutionally protected expectations of privacy. ${ }^{75}$ All of these seem to be variations on the basic policy arguments already mentioned. Their strength has not been authoritatively passed upon by the United States Supreme Court, and the state and lower federal courts that have spoken are divided on them. ${ }^{76}$

73. See, e.g., Brazil, supra note 55, at 623-24; Wolfram, supra note 31, at 840-42.

It is questionable whether the right-to-counsel argument would fare any better in the Supreme Court than have other arguments that, broadly speaking, have claimed a variety of constitutional immunities from impeachments of arguably perjured testimony by the accused. One counterargument to the Sixth Amendment position would be based on Walder v. United States, 347 U.S. 62 (1954); Harris v. New York, 401 U.S. 222 (1971); and Oregon v. Hass, 420 U.S. 714 (1975), holding that evidence or statements of the accused that had been illegally obtained could nonetheless be used as evidence by the prosecution to rebut testimony given by the defendant. See also United States v. Havens, 100 S.Ct. 1912 (1980). In these cases the Court based its result in part upon a rationale that the exclusionary rules should not be "perverted into a license to use perjury by way of a defense." Harris v. New York, 401 U.S. at 226; Oregon v. Hass, 420 U.S. at 721-22; United States v. Havens, 100 S.Ct. at 1916. See also United States v. Salvucci, 100 S.Ct. 2547, 2554 (June 25, 1980) (Court has not yet decided whether testimony of accused at preliminary suppression hearing, which is ordinarily not admissible as evidence of guilt under Simmons v. United States, 390 U.S. 377 (1968), can be used solely for impeachment); Jenkins v. Anderson, 100 S.Ct. 2124 (June 10, 1980) (Fifth Amendment right to remain silent is not infringed by use of prearrest silence of accused to impeach credibility of defendant who elects to testify).

74. See generally Polster, supra note 52, at 16-22; see Lowery v. Cardwell, 575 F.2d 727, 732 (9th Cir. 1978) (Hufstedler, J., concurring) (right to effective assistance of counsel violated by abandonment of client when she perjured herself).

75. See generally Brazil, supra note 55, at 624-39.

76. Compare, e.g., Lowery v. Cardwell, 575 F.2d 727 (9th Cir. 1978) (due process violation when, in bench trial, actions of defense counsel surprised by perjury of defendant-client conveyed clearly to judge belief in guilt of defendant) with McKissick v. United States, 379 F.2d 754, 762 (5th Cir. 1967) (duty of defense counsel to inform court of client's perjury). See also People v. Lewis, 393 N.E.2d 1380 (IIl. App. 1979) (no ineffective assistance of counsel when attorney reveals to court that clientaccused is perpetrating fraud by simulating condition of incompetence in apparent attempt to avoid criminal trial); People v. Schultheis, Colo. App. July 10, 1980, reported in Nat'l L.J.,July 28, 1980, at 3 , col. 2 (defense counsel whose client insists on perjured testimony is allowed to withdraw, and trial judge is required to grant motion; but ineffective assistance of counsel violation occurs when attorney informs judge of reason for motion). 
Most of the scholarly discussion concerning client perjury issues has focused on criminal defense work-an admittedly important area, but one that might be subject to special constitutional considerations making it an inappropriate starting point for considering the problem in civil cases. If one begins, instead, with civil case representation, the great weight of authority supports the position taken in the Kutak-ABA proposal on client perjury and opposes that of the Freedman-ATLA draft.

Take, for example, the specific issue whether a lawyer may ask a client a question in a civil case when, known to the lawyer, the answer will be perjured. Or consider the problem of arguing known perjury to the fact-finder as credible. All of the extant cases ${ }^{27}$ and, with one exception, all commentators ${ }^{78}$ until the publication of the Freedman-ATLA draft have agreed that a lawyer would be subject to professional discipline and possibly other legal sanctions ${ }^{79}$ for such conduct. Accepted at least implicitly as part of this resolution is its price-that of compromising to some extent the willingness of some clients to confide in their lawyers. The civil cases reflect the belief that, to the extent that this will occur, the client has either forgone the protection of counsel because of the client's perjury or, although innocent in rare cases, the client has interests that are not transcendent over those of the search for truth.

The authorities have not as single-mindedly accepted, however, the ultimate and most controversial requirement-active and direct disclosure by the attorney of the client's perjury in a civil case. The original ABA Code of Professional Responsibility, which strongly stated such a requirement, ${ }^{80}$ was amended in 1974 to create an exception to the disclosure obligation whenever the attorney's information came as the result of a client confidence. ${ }^{81}$ That amendment, which has been accepted in very few states, ${ }^{82}$ would be explicitly rejected by the Kutak-ABA proposal. It would be accepted and extended ${ }^{83}$ by the Freedman-ATLA proposals.

Although a lawyer's mandatory disclosure of client perjury in civil cases is supported by most of the cases that have discussed the point, ${ }^{84}$ many people would regard the duty as particularly onerous. Among other considerations, it is argued that the working ethic of the everyday world holds in low regard a "tat-

77. For a collection of authorities see Wolfram, supra note 31, at 847 (asking question); id., at 862 (argument to jury).

78. See Charles P. Curtis, The Ethics of Advocacy, 4 Stan. L. Rev. 3, 10-13 (1951). Even Freedman in his earlier controversial work on client perjury had hinted broadly that his permissive views "might well" not extend to civil cases. See Freedman, Lawyers' Ethics in an Adversary System, supra note 11, at 54.

79. See note 59 supra.

80. DR 7-102(B)(1). For a discussion of the history of the Disciplinary Rule and a collection of authorities see Annotated Code of Professional Responsibility 321-26 (Chicago: American Bar Foundation, 1979).

81. See note 57 supra.

82. See American Bar Association, Committee on Ethics and Professional Responsibility, Code of Professional Responsibility by State, Canon 7, at 17 (1977).

83. The extension would occur through the apparent rule of the Freedman-ATLA proposal that counsel would be required to conduct a "normal" examination of the perjuring client and give a "normal" summation in order not to make an "indirect" divulgence of a client confidence. See text at notes 49-51 supra.

84. See Wolfram, supra note 31, at 865. See also State v. Hoover, 574 P.2d 1377, 1381 (Kan. 1978) (discipline for nondisclosure of false client testimony). 
tletale" who "snitches" on a person, particularly if the person informed on has been induced to trust the informer. ${ }^{85}$ Lawyers can thus be expected to experience peer pressure and perhaps emotional resistance against an obligation to disclose perceived client perjury. A mandatory disclosure rule also creates the risk that an occasional lawyer may misunderstand or misremember a prior client statement and conclude erroneously that present client testimony is false. Innocent clients in that position would be subjected to the humiliation and sense of betrayal caused by having their own words thrown back at them in a highly damaging form by their own advocates. Given the other obligations such as remonstration and withdrawal that are imposed on a lawyer in order to suppress announced intentions of their clients to commit perjury, but under more discreet circumstances and surroundings, it might be thought that a disclosure obligation would likely arise only when a lawyer is unable to prevail upon the client to recant surprise perjury, a case perhaps sufficiently rare that it would not be worth the costs of regulation to require disclosure.

On the other hand, the absence of a rule mandating lawyer disclosure of client perjury would almost certainly create opportunities for unscrupulous lawyers to evade other antiperjury duties such as remonstration and withdrawal. They would thus be in a position of effective impunity from which to cooperate corruptly with clients in the presentation of perjured testimony. All that such a lawyer would need later to defend against a charge of willing cooperation would be his or her own statement-buttressed no doubt by a note in the file and by a client whose own interest would most often be to defend the lawyer's conduct-that a warning of some kind had been given and that knowledge about the perjury was brought home to the lawyer too late to permit withdrawal without divulgence. Neither, of course, would excuse a failure to disclose if that were also required. The extent to which lawyers would succumb to such temptations is, as with most estimates of the incidence of such types of crimes, subject to conjecture. ${ }^{86}$

At this and other points, resolving the client perjury debate calls for an exercise of insight and judgment. The insight that is required in the nature of things must be made without the benefit of any factual basis more solid than anecdotal impressions, personal experience, and tradition. No imaginable experiment based on real-life situations can be devised to determine conclusively whether a disclosure and nonparticipation rule will seriously erode the confidence of clients

85. This consideration, which seems to have considerable strength as revealed in conversation with attorneys, is mitigated by at least two considerations. First, the client should not be led to believe that confidentiality would permit the client to commit perjury. See Kutak-ABA proposal, Rule 1.4(b); id., Comment, at 14 ("A new client should be given a general explanation of the client-lawyer relationship. A client should understand the lawyer's ethical obligations, such as the prohibitions against assisting a client in committing a fraud or presenting perjured evidence"). Second, by the lights of other lawyers, the more appropriate moral response would be to feel concern and outrage at being forced to remain silent in the face of a plain attempt, even by a client, to subvert a trial. See, e.g., John B. Mitchell, The Ethics of the Criminal Defense Attorney-New Answers to Old Questions, 32 Stan. L. Rev. 293, 321-36 (1980); Ordover, supra note 65, at 320.

86. Cf. Jane Berentson, Integrity Test: Five of Thirteen Lawyers Fail, Am. Law., May 1980, at 15 , col. 1 ( 5 of 13 lawyers consulted by lawyer-reporter posing as personal injury claimant expressed willingness to aid and abet perjury necessary to establish claim). 
in their attorneys or the ability of lawyers to extract perceived truth even from skeptical clients. No more can it be proved that the absence of such a rule will create an unacceptable incidence of corruption of the trial process through client perjury. ${ }^{87}$ For many, doubtless, the choice will be influenced by their view of the courtroom and the wider world outside it. Some believe that the polity is basically good and regularly well run. For these, who believe also that the adversary system is characterized largely by sound procedures in fair tribunals administering just laws, it will be more evident that the mutual trust that holds the system together requires strong measures to resist falsity. For others the perception of the litigant in the modern courtroom is that of the embattled victim of a system that is vicious when it is not uncaring, often with the person's own government acting as the oppressor. ${ }^{88}$ This view of the setting more naturally justifies the use of even the most unpleasant weapons in the lawyer's arsenal.

87. There is no reason to think that judgments about such matters will reflect any national consensus or nationwide uniformity of conditions. It might occur that individual jurisdictions will see fit to resolve the disclosure and nonparticipation problems in ways that better reflect local conditions and local sentiments. The professional rule-drafting groups could still perform a very useful role by offering to the local lawyer disciplinary agencies-primarily the highest court of each state-different model provisions with different blends of obligations.

88. For a widesweeping critique along these general lines, see William H. Simon, The Ideology of Advocacy: Procedural Justice and Professional Ethics, 1978 Wisc. L. Rev. 29. See also Mitchell, supra note 85. 